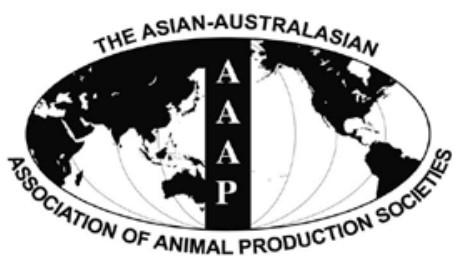

Asian-Aust. J. Anim. Sci.

Vol. 25, No. 1 : 75 - 85

January 2012

www.ajas.info

http://dx.doi.org/10.5713/ajas.2011.11146

\title{
Feeding Unprotected CLA Methyl Esters Compared to Sunflower Seeds Increased Milk CLA Level but Inhibited Milk Fat Synthesis in Cows
}

\author{
F. Dohme-Meier* and G. Bee \\ Agroscope Liebefeld-Posieux, Research Station ALP, 1725 Posieux, Switzerland
}

\begin{abstract}
An experiment was conducted to compare the effect of the same amount of $18: 2$ offered either as $18: 2 n-6$ or as a mixture of unprotected 18:2c9t11 and 18:2t10c12 on feed intake, milk components as well as plasma and milk fatty acid profile. Fifteen cows were blocked by milk yield and milk fat percentage and within block assigned randomly to 1 of 3 treatments $(n=5)$. Each cow passed a 12-d adjustment period (AP) on a basal diet. After the AP cows received 1 of 3 supplements during an 18-d experimental period (EP). The supplements contained either $1.0 \mathrm{~kg}$ ground sunflower seeds (S), $0.5 \mathrm{~kg}$ conjugated linoleic acid (CLA)-oil (C) or $0.75 \mathrm{~kg}$ of a mixture of ground sunflower seeds and CLA-oil (2:1; SC). All 3 supplements contained the same amount of 18:2 either as CLA $\left(\sum 18: 2 c 9 t 11+18: 2 t 10 c 12,1: 1\right)$ or as 18:2c9c12. During the last $2 \mathrm{~d}$ of AP and the last $4 \mathrm{~d}$ of EP feed intake and milk yield were recorded daily and milk samples were collected at each milking. Blood samples were collected from the jugular vein on d 11 of AP and d 15 and 18 of EP. The 18:2 intake increased in all treatments from AP to EP. Regardless of the amount of supplemented CLA, the milk fat percentage decreased by 2.35 and $2.10 \%$-units in treatment C and SC, respectively, whereas in the treatment S the decrease was with 0.99\%-unit less pronounced. Thus, C and SC cows excreted daily a lower amount of milk fat than S cows. The concentration of trans 18:1 in the plasma and the milk increased from AP to EP and increased with increasing dietary CLA supply. While the concentration of $18: 2 c 9 t 11$ and $18: 2 t 10 c 12$ in the plasma and that of $18: 2 t 10 c 12$ in the milk paralleled dietary supply, the level of $18: 2 c 9 t 11$ in the milk was similar in C and CS but still lower in S. Although the dietary concentration of CLA was highest in treatment C, the partial replacement of CLA by sunflower seeds had a similar inhibitory effect on milk fat synthesis. Comparable 18:2c9t11 levels in the milk in both CLA treatments implies that this isomer is subjected to greater biohydrogenation with increasing supply than $18: 2 t 10 c 12$. The fact that unprotected 18:2t10c12 escaped biohydrogenation in sufficient amounts to affect milk fat synthesis reveals opportunities to develop feeding strategies where reduced milk fat production is desirable or required by the metabolic state of the cow. (Key Words : CLA-oil, Dairy Cow, Milk Fat, Sunflower Seeds)
\end{abstract}

\section{INTRODUCTION}

Feeding lactating dairy cows diets supplemented with oilseeds rich in 18:2n-6 reduce markedly milk saturated fatty acid content and, concomitantly, enhance milk lipid 18:2cis(c)9trans(t)11 conjugated linoleic acid (CLA) concentration (Collomb et al., 2004). The latter is the most abundant CLA isomer in the milk and is formed in the rumen during 18:2n-6 biohydrogenation $(\mathrm{BH})$ and endogenously in the mammary gland from ruminally derived 18:1t11 by $\Delta 9$-desaturase (Griinari et al., 2000; Mosley et al., 2006). The 18:2n-6 BH rate depends on factors such as dietary forage (Sackmann et al., 2003) or dietary fat supplementation levels (Duckett et al., 2002).

\footnotetext{
* Corresponding Author : F. Dohme-Meier. Tel: +41-26-4077227, Fax: +41-26-4077300, E-mail: frigga.dohme-meier@alp.admin.ch Received May 21, 2011; Accepted August 22, 2011
}

For instance, 18:2n-6 BH rates varied between 78 and 84\% in steers fed high concentrate diets with increasing dietary fat content (Duckett et al., 2002) while even higher $\mathrm{BH}$ rates, ranging from 92 to $98 \%$, were reported when dairy cows were offered forage-based diets supplemented with increasing levels of sunflower oil (Shingfield et al., 2008). Independently of the added fat level, results obtained in vitro revealed nearly complete $\mathrm{BH}$ of 18:2n-6 derived from cottonseed oil after 24 h incubation (Gulati et al., 1999). The major intermediates of $18: 2 \mathrm{n}-6 \mathrm{BH}$ are $18: 2 c 9 t 11$, 18:1t11 and 18:0 (Shingfield et al., 2008). However, under certain dietary circumstances like increased 18:2n-6 supply or feeding low forage diets, elevated amounts of 18:2t10c12 can be produced by ruminal BH (Duckett et al., 2002; Sackmann et al., 2003). It is well established that with increasing 18:2t10c12 concentrations in the milk its fat content decreases due to inhibited milk fat synthesis 
(Baumgard et al., 2000; De Veth et al., 2004). However, as for 18:2c9t11, only a small amount of the produced $18: 2 t 10 c 12$ escapes BH to $18: 1 t 10$. Duckett et al. (2002) found that depending on dietary treatment, the percentage of 18:2n-6 intake reaching the duodenum as $18: 1 t 11$ and $18: 1 t 10$ was ten to fifty-fold higher than that of $18: 2 c 9 t 11$ and $18: 2 t 10 c 12$. Thus, it is plausible to suggest that conversion from $18: 2 c 9 t 11$ to $18: 1 t 11$ and $18: 2 t 10 c 12$ to 18:1t10 occurs faster than from 18:1t10 and 18:1t11 to 18:0. In accordance, data of a recent study with dairy cows abomasally infused with labeled 18:1t11 revealed that approximately $80 \%$ of $18: 2 c 9 t 11$ in the milk fat resulted from desaturation of $18: 1 \mathrm{t} 11$ in the mammary gland (Mosley et al., 2006). In a study with lactating cows increases in milk fat 18:2c9t11 content to abomasal infusion of a mixture of fatty acids containing 18:1t11 are equivalent to proportionally $21 \%$ of the response after $18: 2 c 9 t 11$ infusion (Shingfield et al., 2007). Based on these results, Shingfield et al. (2008) concluded that 18:2c9t11 accumulation in the rumen represents the most efficient way to enhance the concentration of this CLA isomer in milk fat. Furthermore, they demonstrated that with increasing levels of sunflower oil in the diet the ruminal outflow of 18:2c9t11 can be enhanced. In accordance, results obtained in vitro showed that with increasing amounts of soybean oil as substrate 18:2n-6 BH is slower and less complete (Beam et al., 2000). The authors speculated that the reason might be a competitive inhibition of isomerase enzyme activity by the fatty acid end products. Shingfield et al. (2008) concluded from their results that the population of ruminal bacteria changed due to a toxic effect of $18: 2 n-6$ on sensitive strains when fat supplementation increased.

Another successful approach to increase the 18:2c9t11 concentration in the milk is by feeding protected CLA (Castaneda-Gutierrez et al., 2005; Gulati et al., 2000). However, to our knowledge, nothing is known about the influence of feeding elevated amounts of unprotected CLA to dairy cows. Thus, the objective of the present study was to compare the effects of feeding unprotected CLA methyl esters, sunflower seeds and a mixture of both to an unsupplemented control and among each other on feed intake, milk components and the transfer of fatty acids from the feed to the milk fat.

\section{MATERIALS AND METHODS}

\section{Experimental design, animals and feeding}

The experiment was based on a mono-factorial design. Twelve multiparous and 3 primiparous Holstein and Brown Swiss cows were blocked by milk yield and milk fat percentage and within block randomly equally assigned to one of 3 treatments $(n=5)$. At the beginning of the experiment, cows on average were 129 \pm 30 DIM (mean \pm
SD), had a BW of $669 \pm 43 \mathrm{~kg}$ and produced $32.6 \pm 5.39 \mathrm{~kg} / \mathrm{d}$ of milk with $4.12 \pm 0.500 \%$ fat and $3.26 \pm 0.205 \%$ protein. Each cow passed a 12-d adjustment period (AP) on a basal diet, which comprised hay and fodder beets for ad libitum intake. Furthermore, a cereal mix (barley:corn:wheat; 1:1:1) and a soybean meal-based protein concentrate were allocated according to the milk yield and BW. Additionally, all cows received $300 \mathrm{~g} / \mathrm{d}$ of a mineral mix containing per kg: 91.5 g Ca, 54.0 g P, 66.3 g Na, 15.0 g Mg, 450 mg Mn, 325 mg Zn, 119 mg Cu, 17.1 mg I, 5.06 mg Se, and 3.59 mg Co. To facilitate the pelleting process and to ensure the complete consumption of the supplement minerals were mixed with $50 \mathrm{~g} / \mathrm{kg}$ fat, $280 \mathrm{~g} / \mathrm{kg}$ corn and $110 \mathrm{~g} / \mathrm{kg}$ wheat middlings. After being accustomed to the basal diet cows received one of 3 supplements during a 18-d experimental period (EP). The supplements contained either $1.0 \mathrm{~kg}$ ground sunflower seeds (S), $0.5 \mathrm{~kg}$ CLA-oil (C) or $0.75 \mathrm{~kg}$ of a mixture of ground sunflower seeds and CLA-oil (2:1; SC). The seeds and oil were blended with wheat middling and molasses $(0.06 \mathrm{~kg} / \mathrm{d})$ so that each cow was fed $2.0 \mathrm{~kg} / \mathrm{d}$ of the supplement. In order to estimate the transfer success into the milk of unprotected CLA compared to CLA from sunflower seeds, all 3 supplements contained the same amount of 18:2 either as CLA or as 18:2n-6 (Table 1). The CLA-oil (BASF-AG, Offenbach, Germany) was supplied as methyl ester, with a total CLA concentration of $60 \%$ equally composed of 18:2c9t11 and 18:2t10c12 isomers.

\section{Experimental technique}

Cows were housed in a free-stall barn and fed using a feeding station and roughage weighing troughs (Insentec BV, Marknesse, The Netherlands). Feed intake was automatically recorded daily for each cow. Feed samples were taken every day, then pooled over the AP and EP, and subsequently stored at $-20^{\circ} \mathrm{C}$. Cows were milked in the milking parlor at 0530 and $1600 \mathrm{~h}$. Milk yield was determined at each milking and 3 aliquots from each milking were collected on $\mathrm{d} 11$ and 12 of the AP and on d $15,16,17$, and 18 of the EP. One sample was preserved with Broad Spectrum Microtabs (Gerber Instruments AG, Effretikon, Switzerland) and stored at $5^{\circ} \mathrm{C}$ for subsequent analysis of fat, protein, lactose and urea. The second sample was frozen at $-20^{\circ} \mathrm{C}$ and used for urea $\mathrm{N}$ content determination. The third sample was pooled for $\mathrm{d} 10$ and 12 of the AP and for d 15 and 16 and d 17 and 18 of the EP and frozen at $-20^{\circ} \mathrm{C}$ for the determination of the fatty acid composition. Blood was sampled from the jugular vein directly after the morning milking on $\mathrm{d} 11$ of the AP and on d 15 and 18 of the EP in vacuum tubes, cooled on ice, and centrifuged at $1,500 \times \mathrm{g}$ for $15 \mathrm{~min}$ and stored at $-20^{\circ} \mathrm{C}$. Plasma and serum (only for NEFA analysis) were produced using heparinized vacuettes (Greier Bioone, Solingen, Germany) or containers without anticoagulant. The 
Table 1. Chemical composition of diets ingredients

\begin{tabular}{|c|c|c|c|c|c|c|c|}
\hline & \multicolumn{4}{|c|}{ Basel diet } & \multicolumn{3}{|c|}{ Treatment supplements $^{1}$} \\
\hline & Hay & Fodder beets & Cereal mix & $\begin{array}{c}\text { Protein } \\
\text { concentrate }\end{array}$ & S & $\mathrm{C}$ & SC \\
\hline \multicolumn{8}{|c|}{$\begin{array}{l}\text { Analyzed nutrient composition } \\
\text { (g/kg of DM) }\end{array}$} \\
\hline DM (g/kg wet wt) & 906 & 203 & 872 & 892 & 917 & 909 & 917 \\
\hline $\mathrm{OM}$ & 883 & 906 & 953 & 954 & 949 & 946 & 951 \\
\hline $\mathrm{CP}$ & 160 & 47.8 & 126 & 574 & 153 & 126 & 137 \\
\hline NDF & 442 & 107 & 132 & 142 & 332 & 362 & 331 \\
\hline Total fatty acids & 12.1 & 1.53 & 23.3 & 55.4 & 253 & 270 & 281 \\
\hline \multicolumn{8}{|c|}{$\begin{array}{l}\text { Calculated contents of absorbable protein } \\
\text { and net energy (per kg DM) }{ }^{2}\end{array}$} \\
\hline Absorbable protein (g) & 98.2 & 80.1 & 113 & 311 & 63.3 & 62.1 & 62.3 \\
\hline $\mathrm{NE}_{\mathrm{L}}(\mathrm{MJ})$ & 5.91 & 7.53 & 7.92 & 8.11 & 10.00 & 11.21 & 10.70 \\
\hline \multicolumn{8}{|l|}{$\begin{array}{l}\text { Fatty acid composition } \\
\text { (g/100 g total fatty acids) }\end{array}$} \\
\hline $16: 0$ & 17.80 & 23.33 & 15.52 & 14.56 & 6.88 & 6.66 & 6.68 \\
\hline 18:0 & 1.69 & -3 & 1.97 & 3.44 & 4.21 & 4.10 & 4.12 \\
\hline $18: 1 n-9$ & 2.97 & 16.67 & 21.43 & 22.35 & 18.53 & 21.49 & 20.04 \\
\hline $18: 2 n-6$ & 17.37 & 53.33 & 57.39 & 51.47 & 68.15 & 7.68 & 36.25 \\
\hline $18: 3 n-3$ & 60.17 & 6.67 & 3.69 & 6.57 & 0.44 & 0.49 & 0.47 \\
\hline $18: 2 c 9 t 12$ & - & - & - & - & - & 29.11 & 15.25 \\
\hline $18: 2 t 10 c 12$ & - & - & - & - & - & 28.73 & 15.41 \\
\hline
\end{tabular}

${ }^{1} \mathrm{~S}=$ Mixture of ground sunflower seeds, wheat middlings, molasses; C = Mixture of CLA-oil, wheat middlings, molasses; SC = Mixture of ground sunflower seeds, CLA-oil, wheat middlings, molasses.

${ }^{2}$ According to RAP (1999).

${ }^{3}-<0.01$.

experiment was conducted in accordance with the Swiss guidelines for animal welfare and approved by the respective authority.

\section{Laboratory analyses}

The preserved and refrigerated milk samples were analyzed by infrared spectrometry (Combis-Foss, Gerber Instruments AG, Effretikon, Switzerland) for their contents of fat, protein, lactose, and urea (FIL-IDF, 2000). In the frozen milk samples the urea $\mathrm{N}$ content were enzyme kinetically analyzed (test kit no. 61 974, UV 250, bioMérieux, Lyon, France). The pooled frozen milk samples and the plasma samples were analyzed for their fatty acid composition. After dissolution of the pure milk fat in hexane, the glycerides were transesterified to the corresponding methyl esters of fatty acids by a solution of potassium hydroxide in methanol. The plasma samples were extracted with a solution of hexane-isopropanol 2:3 (v:v), the triglycerides transesterified with a mixture of $\mathrm{NaOH} / \mathrm{CH}_{3} \mathrm{OH}$, and the free fatty acids esterified with an excess of $\mathrm{BF}_{3}$ in $\mathrm{CH}_{3} \mathrm{OH}$. For the two products, the fatty acids were separated on a capillary column CP-Sil 88 (100 $\mathrm{m} \times 0.25 \mathrm{~mm}$ i.d. $\times 0.20 \mu \mathrm{m})$ according to Collomb and Bühler (2000).
The concentrations of metabolites in the blood were determined enzymatically using the following commercial test kits: triglycerides, no. 61 236, bioMérieux; cholesterol, no. 61 219, bioMérieux; HDL, no. 61 530, bioMérieux; LDL, no. 61 534, bioMérieux; NEFA FA 115, Randox, Crumlin, UK.

Prior to laboratory analysis, fodder beets and hay samples were dried at $60^{\circ} \mathrm{C}$ for $12 \mathrm{~h}$. Afterwards all feed samples were ground to pass through a $1.0-\mathrm{mm}$ screen (Brabender mill no. 880804, Brabender, Duisburg, Germany) and chemical composition was determined in duplicate. The DM content was measured by oven-drying at $105^{\circ} \mathrm{C}$ for $3 \mathrm{~h}$ and $\mathrm{OM}$ was determined by ashing at $550^{\circ} \mathrm{C}$ for $4 \mathrm{~h}$. The NDF content was analyzed according to Mertens (2002) using heat stable amylase (A3306 Sigma, Grogg Chemie AG, Stettlen-Deisswil, Switzerland) and expressed without residual ash. Nitrogen $(\mathrm{N})$ contents of the feeds were measured with the Dumas method (AOAC, 1990) on a C/N analyzer (type FP-2000, Leco Instruments, St. Joseph, MI, USA). Fatty acids were extracted from the feed with dichlormethan/methanol 2:1 (v:v) after adding methyl tridecanoate as internal standard. The preparation of the fatty acid methyl esters (FAME) by transesterification was carried out according to IUPAC (1987). FAME were 
quantified by using a GC (HP 5890, Hewlett Pacckard, Waldbronn, Germany) equipped with a Supelcowax 10 capillary column $(30 \mathrm{~m} \times 0.32 \mathrm{~mm} \quad$ i.d. $\times 0.25 \mu \mathrm{m} \quad$ film thickness, Supelco, Bellefonte, PA, USA).

\section{Calculations and statistical analysis}

The dietary contents of absorbable protein at the duodenum and $\mathrm{NE}_{\mathrm{L}}$ were calculated according to ALP (2008). The CP content of feed was calculated as $6.25 \times \mathrm{N}$ content. All statistical analyses were conducted using PROC MIXED of SAS Institute (2004). Within treatments, the period (AP vs. EP) was used as the fixed effect in the model. In addition, in the AP and EP, data were evaluated by analysis of variance with treatment groups as the fixed effect. Multiple comparisons between means in AP and EP and among means in the EP were carried out using the PDIFF statement. Effects were considered significant at $\mathrm{p}<0.05$. If differences occurred between treatment groups in the AP the p-values were reported in the text.

\section{RESULTS}

\section{Feed, nutrient intake and animal performance}

Compared to the AP, C and SC cows consumed less $(\mathrm{p}<0.05)$ hay than $\mathrm{S}$ cows in the EP (Table 2). Nevertheless, the NDF intake did not differ $(p>0.05)$ because of the different NDF composition of the supplements (Table 1) and their slightly different intake. In all treatments the allocation of the protein concentrate decreased $(\mathrm{p} \geq 0.05)$ from the AP to the EP and therefore the intake of absorbable protein decreased $(\mathrm{p}<0.05$; except in treatment $\mathrm{S})$. Except for the lower $(\mathrm{p}<0.05)$ 18:3n-3 intake in $\mathrm{C}$ and SC treatments, the intake of total and individual fatty acid increased $(\mathrm{p}<0.01)$ from the AP to the EP. The lower $18: 3 n-3$ intake can be explained by the lower $(p<0.01)$ hay intake.

As planned, the same ( $>00.05)$ 18:2 intake in form of either $18: 2 n-6$, CLA (18:2c9t11 or a mixture of $18: 2 n-6$ and CLA was obtained in the 3 treatments (Table 2). In the EP the 18:0 intake was $1.5 \mathrm{~g} / \mathrm{d}$ lower $(\mathrm{p}<0.05)$ in the SC compared to the other 2 treatments. Because of the slightly higher 18:1n-9 content of the $\mathrm{C}$ and SC supplements, these cows ingested more $(\mathrm{p}<0.01) 18: 1 \mathrm{n}-9$ than $\mathrm{S}$ cows.

Within treatments, the milk yield did not $(\mathrm{p} \geq 0.23)$ differ between AP and EP (Table 3). Regardless of the amount of supplemented CLA, the milk fat percentage decreased ( $<<0.01$ ) by 2.35 and $2.10 \%$-units in the $\mathrm{C}$ and SC treatments, respectively, whereas in the $S$ treatment the decrease was less pronounced (0.99\%-units; $\mathrm{p}>0.05)$. Therefore, the reduction in the amount of daily secreted fat was highest in the $\mathrm{C}(-60 \% ; \mathrm{p}<0.01)$, followed by the SC $(-47 \% ; \mathrm{p}<0.01)$ and $\mathrm{S}$ group $(-20 \% ; \mathrm{p}<0.01)$. However, the amount of ECM was reduced $(\mathrm{p}<0.01)$ only in treatment $\mathrm{C}$. Numerically lower $(p=0.05)$ urea concentrations were observed in the SC treatment.

During the EP no treatment effects on milk yield occurred ( $>00.05$; Table 3 ). The milk fat percentage was lower $(p<0.01)$ in cows fed the C or SC compared to those

Table 2. Feed and nutrient intake

\begin{tabular}{|c|c|c|c|c|c|c|c|c|c|c|c|c|c|c|}
\hline \multirow{2}{*}{$\begin{array}{l}\text { Treatment }^{2} \\
\text { Period }^{3}\end{array}$} & \multicolumn{4}{|c|}{$\mathrm{S}$} & \multicolumn{4}{|c|}{$\mathrm{C}$} & \multicolumn{4}{|c|}{ SC } & \multicolumn{2}{|c|}{ Treatment } \\
\hline & AP & EP & SEM & p value & AP & EP & SEM & p value & AP & EP & SEM & $\mathrm{p}$ value & SEM & $\mathrm{p}$ value \\
\hline \multicolumn{15}{|l|}{ Intake (DM/cow per d) } \\
\hline Hay (kg) & 14.7 & 14.0 & 0.85 & 0.55 & 15.2 & 12.9 & 0.45 & $<0.01$ & 15.8 & 13.7 & 0.57 & $<0.05$ & 0.67 & 0.52 \\
\hline Fodder beets (kg) & 3.10 & 3.19 & 0.04 & 0.14 & 2.83 & 2.60 & 0.28 & 0.57 & 3.11 & 3.08 & 0.046 & 0.61 & 0.20 & 0.13 \\
\hline Cereal mix (kg) & 3.45 & 2.53 & 0.64 & 0.34 & 3.28 & 2.42 & 0.54 & 0.30 & 3.29 & 2.35 & 0.59 & 0.29 & 0.55 & 0.98 \\
\hline Protein concentrate (g) & 702 & 142 & 89.7 & $<0.01$ & 628 & 174 & 119.3 & $<0.05$ & 701 & 107 & 76.0 & $<0.01$ & 65.7 & 0.77 \\
\hline Supplement (kg) & - & 1.84 & & & - & 1.85 & & & - & 1.87 & & & 0.014 & 0.44 \\
\hline Total (kg) & 22.3 & 22.0 & 0.90 & 0.82 & 22.3 & 20.2 & 0.63 & 0.05 & 23.1 & 21.4 & 0.72 & 0.12 & 0.76 & 0.30 \\
\hline NDF (kg) & 7.45 & 7.54 & 0.351 & 0.86 & 7.62 & 7.05 & 0.199 & 0.08 & 7.90 & 7.38 & 0.243 & 0.18 & 0.286 & 0.49 \\
\hline Absorbable protein $(\mathrm{kg})$ & 2.31 & 2.08 & 0.104 & 0.16 & 2.29 & 1.92 & 0.083 & $<0.05$ & 2.39 & 2.01 & 0.088 & $<0.05$ & 0.084 & 0.45 \\
\hline NEL (MJ) & 144 & 147 & 6.1 & 0.75 & 143 & 138 & 4.5 & 0.45 & 149 & 144 & 5.2 & 0.55 & 5.18 & 0.47 \\
\hline Total fatty acids (g) & 314 & 718 & 17.9 & $<0.01$ & 311 & 739 & 19.4 & $<0.01$ & 322 & 769 & 16.5 & $<0.01$ & 16.3 & 0.13 \\
\hline $16: 0$ & 52.6 & 75.2 & 2.83 & $<0.01$ & 52.4 & 73.9 & 2.72 & $<0.01$ & 54.2 & 76.7 & 2.56 & $<0.01$ & 2.40 & 0.70 \\
\hline 18:0 & 11.3 & $29.3^{\mathrm{b}}$ & 0.41 & $<0.01$ & 11.1 & $29.9^{\mathrm{b}}$ & 0.51 & $<0.01$ & 11.4 & $31.1^{\mathrm{a}}$ & 0.38 & $<0.01$ & 0.38 & $<0.05$ \\
\hline $18: 1 c 9$ & 34.3 & $109.0^{\mathrm{b}}$ & 4.09 & $<0.01$ & 32.6 & $129.6^{\mathrm{a}}$ & 4.36 & $<0.01$ & 33.9 & $126.6^{\mathrm{a}}$ & 3.67 & $<0.01$ & 3.6 & $<0.01$ \\
\hline $\begin{array}{l}\sum(18: 2 \mathrm{n}-6,18: 2 \mathrm{c} 9 \mathrm{t} 11 \\
18: 2 \mathrm{t} 10 \mathrm{c} 12)\end{array}$ & 101 & 390 & 10.2 & $<0.01$ & 97 & 400 & 11.2 & $<0.01$ & 101 & 422 & 9.3 & $<0.01$ & 9.3 & 0.08 \\
\hline $18: 3 n-3$ & 113 & 107 & 5.92 & 0.48 & 117 & 100 & 3.1 & $<0.01$ & 121 & 105 & 4.0 & $<0.05$ & 4.7 & 0.52 \\
\hline Saturated FA & 65 & 110 & 3.2 & $<0.01$ & 64 & 107 & 3.3 & $<0.01$ & 66 & 113 & 2.9 & $<0.01$ & 2.8 & 0.29 \\
\hline Unsaturated FA & 249 & 608 & 14.7 & $<0.01$ & 247 & 632 & 16.1 & $<0.01$ & 256 & 656 & 13.5 & $<0.01$ & 13.5 & 0.08 \\
\hline
\end{tabular}


Table 3. Milk yield and composition ${ }^{1}$

\begin{tabular}{|c|c|c|c|c|c|c|c|c|c|c|c|c|c|c|}
\hline \multirow{2}{*}{$\begin{array}{l}\text { Treatment }^{2} \\
\text { Period }^{3}\end{array}$} & \multicolumn{4}{|c|}{$\mathrm{S}$} & \multicolumn{4}{|c|}{$\mathrm{C}$} & \multicolumn{4}{|c|}{ SC } & \multicolumn{2}{|c|}{ Treatment } \\
\hline & $\mathrm{AP}$ & $\mathrm{EP}$ & SEM & $\bar{p}$ value & $\mathrm{AP}$ & $\mathrm{EP}$ & SEM & $\overline{p \text { value }}$ & $\mathrm{AP}$ & $\mathrm{EP}$ & SEM & $p$ value & SEM & $p$ value \\
\hline \multicolumn{15}{|l|}{ Yield (kg/cow per d) } \\
\hline Milk & 30.3 & 30.4 & 1.91 & 0.97 & 30.1 & 26.1 & 2.21 & 0.23 & 27.1 & 29.0 & 2.29 & 0.58 & 2.21 & 0.40 \\
\hline $\mathrm{ECM}^{4}$ & 31.8 & $28.6^{\mathrm{a}}$ & 1.24 & 0.10 & 31.0 & $20.1^{\mathrm{b}}$ & 1.30 & $<0.01$ & 27.9 & $22.5^{\mathrm{b}}$ & 1.95 & 0.08 & 1.62 & $<0.01$ \\
\hline Fat & 1.37 & $1.10^{\mathrm{a}}$ & 0.053 & $<0.01$ & 1.29 & $0.52^{\mathrm{b}}$ & 0.048 & $<0.01$ & 1.12 & $0.59^{\mathrm{b}}$ & 0.083 & $<0.01$ & 0.058 & $<0.01$ \\
\hline Protein & 0.98 & 0.96 & 0.069 & 0.81 & 0.99 & 0.94 & 0.048 & 0.51 & 0.93 & 0.99 & 0.061 & 0.49 & 0.060 & 0.83 \\
\hline Lactose & 1.43 & 1.46 & 0.098 & 0.81 & 1.46 & 1.22 & 0.102 & 0.14 & 1.35 & 1.45 & 0.108 & 0.54 & 0.102 & 0.21 \\
\hline \multicolumn{15}{|l|}{ Composition } \\
\hline Fat (\%) & 4.63 & $3.64^{\mathrm{a}}$ & 0.338 & 0.07 & 4.37 & $2.02^{\mathrm{b}}$ & 0.252 & $<0.01$ & 4.1 & $2.00^{\mathrm{b}}$ & 0.128 & $<0.01$ & 0.108 & $<0.01$ \\
\hline Protein (\%) & 3.23 & 3.15 & 0.060 & 0.36 & 3.32 & 3.63 & 0.141 & 0.15 & 3.43 & 3.46 & 0.112 & 0.87 & 0.130 & 0.06 \\
\hline Lactose (\%) & 4.71 & $4.82^{b}$ & 0.058 & 0.23 & 4.85 & $4.69^{\mathrm{b}}$ & 0.056 & 0.07 & 4.98 & $5.01^{\mathrm{a}}$ & 0.055 & 0.64 & 0.057 & $<0.01$ \\
\hline Urea-N (mg/kg) & 86.5 & 88.7 & 7.68 & 0.84 & 97.1 & 80.0 & 6.03 & 0.08 & 87.5 & 74.0 & 4.18 & 0.05 & 4.81 & 0.14 \\
\hline
\end{tabular}

${ }^{1}$ Means within the same row with unequal superscripts are significantly different $(\mathrm{p}<0.05)$.

${ }^{2} \mathrm{~S}=$ Mixture of ground sunflower seeds, wheat middlings, molasses; $\mathrm{C}=$ Mixture of CLA-oil, wheat middlings, molasses; SC = Mixture of ground sunflower seeds, CLA-oil, wheat middlings, molasses.

${ }^{3} \mathrm{AP}=$ Adjustment period; EP, experimental period.

${ }^{4} \mathrm{ECM}=$ Energy corrected milk.

fed the $\mathrm{S}$ diet. This resulted in a $50 \%$ lower $(\mathrm{p}<0.01)$ amount of milk fat secreted and a $25 \%$ lower $(\mathrm{p}<0.01)$ amount of ECM in the $\mathrm{C}$ and SC treatments. The percentage of milk lactose was higher $(\mathrm{p}<0.01)$ in the SC compared to the $\mathrm{S}$ and $\mathrm{C}$ treatments. However, one should be aware that in the AP the milk lactose percentage was lower $(\mathrm{p}<0.05)$ in treatment $\mathrm{S}$ compared to $\mathrm{C}$ and SC.

\section{Blood metabolites and fatty acid composition of the plasma}

Compared to the AP, the triglyceride concentration in the plasma increased $(\mathrm{p}<0.01)$ in all treatments, whereas the NEFA concentration increased $(\mathrm{p}<0.05)$ by $150 \%$ in the $C$ and SC treatments but not in treatment S (Table 4). Higher $(p<0.05)$ HDL concentrations were determined in cows fed the CLA containing supplements (C and SC) but cholesterol level was higher $(\mathrm{p}<0.01)$ only in the SC treatment.

The concentration of the odd chain fatty acid 15:0 in the plasma decreased $(\mathrm{p}<0.01)$ when CLA supplemented diets ( $C$ and SC) were offered in the EP, whereas when sunflower seeds (S and SC) were offered the 19:0 level decreased $(\mathrm{p}<0.05$; Table 4). Regardless of the dietary treatments, the 17:0 plasma level was lower in the EP than in the AP. From the AP to the EP, the plasma concentration of 14:0 and 18:0 only increased $(\mathrm{p}<0.05)$ in the $\mathrm{S}$, that of $16: 0$ decreased $(p<0.01)$ in the $C$ and SC, and that of 20:0 decreased $(p<0.01)$ only in the SC treatment. When switching to the experimental diets, in $\mathrm{S}$ cows the $14: 1 \mathrm{n}-5,16: 1 \mathrm{n}-7$, and $18: 1 n-9$ plasma concentrations increased $(\mathrm{p}<0.05)$, in $\mathrm{C}$ cows only the $18: 1 n-9$ level were higher $(p<0.05)$ whereas in SC cows their plasma concentrations remained unchanged. Contrarily, the 20:1n-9 level decreased $(\mathrm{p}<0.05)$ when sunflower seeds ( $S$ and $S C)$ were offered in the EP. Regardless of the treatments, the concentrations of the sum of the $18: 1 t 10 / 18: 1 t 11$, the $18: 1 c 9 t 11$ and the sum of all detected CLA isomers increased $(\mathrm{p}<0.05)$ from AP to EP. However, the concentration of the other major CLA isomer, 18:1t10,c12, increased $(\mathrm{p}<0.01)$ when supplied by the CLA-oil supplemented diet ( $\mathrm{C}$ and SC), and its concentration decreased $(\mathrm{p}<0.01)$ when only sunflower seed supplement was offered (S). In the SC but not the other treatments the 20:3n-6 concentration was higher $(p<0.01)$ in the AP than EP.

Because differences already existed in the concentrations of several fatty acids among treatments in the AP, the comparison of the treatment effects in the EP needs to be discussed with caution. When the fat source was solely CLA, the plasma concentrations of $20: 0,16: 1 n-7$, $18: 1 n-9,18: 1 t 10 / t 11$, and 20:1n-11 were higher $(\mathrm{p}<0.05)$ and when the fat source was solely sunflower seed the 17:0 concentration was higher $(\mathrm{p}<0.01)$. The $18: 2 n-6$ and the CLA isomer plasma concentrations reflected $(\mathrm{p}<0.01)$ the different fatty acid composition of the supplements (Table 1) and thus the different fatty acid intake (Table 2). Although the consumed amount of $18: 3 n-3$ was similar for all treatments (Table 2), the 18:3n-3 plasma concentration was highest in $\mathrm{C}$, lowest in $\mathrm{S}$ and intermediate in SC $(p<0.01)$.

\section{Fatty acid composition of the milk fat}

The short chain fatty acid (SCFA; 4:0, 6:0, 8:0, 10:0) concentration decreased $(\mathrm{p}<0.01)$ from AP to EP in cows fed the $\mathrm{C}$ and SC diets, whereas in the milk of S cows their concentrations remained unchanged ( $\mathrm{p} \geq 0.07$; Table 5). Switching from the adaptation diet to the experimental diets resulted in lower $(\mathrm{p}<0.05)$ concentrations of saturated medium chain fatty acids (MCFA; 12:0, 14:0, 15:0, 16:0) in all 3 treatments and lower $(\mathrm{p}<0.05)$ 17:0 concentrations in treatment S. The decrease in SCFA and MCFA from the AP to the EP were compensated by higher $(\mathrm{p}<0.01)$ 
Table 4. Metabolites and fatty acid composition of the blood ${ }^{1}$

\begin{tabular}{|c|c|c|c|c|c|c|c|c|c|c|c|c|c|c|}
\hline \multirow{2}{*}{$\begin{array}{l}\text { Treatment } \\
\text { Period }^{3}\end{array}$} & \multicolumn{4}{|c|}{$\mathrm{S}$} & \multicolumn{4}{|c|}{$\mathrm{C}$} & \multicolumn{4}{|c|}{ SC } & \multicolumn{2}{|c|}{ Treatment } \\
\hline & AP & EP & SEM & $\mathrm{p}$ value & AP & EP & SEM & p value & $\mathrm{AP}$ & EP & SEM & $\overline{p \text { value }}$ & SEM & $\mathrm{p}$ value \\
\hline \multicolumn{15}{|c|}{ Metabolites (mmol/L) } \\
\hline Triglycerides & 0.185 & 0.321 & 0.0202 & $<0.01$ & 0.174 & 0.306 & 0.0157 & $<0.01$ & 0.217 & 0.338 & 0.0203 & $<0.01$ & 0.0188 & 0.50 \\
\hline NEFA & 0.066 & $0.062^{\mathrm{b}}$ & 0.0049 & 0.64 & 0.055 & $0.091^{\mathrm{a}}$ & 0.0041 & $<0.01$ & 0.050 & $0.097^{\mathrm{a}}$ & 0.0098 & $<0.05$ & 0.0064 & $<0.01$ \\
\hline Cholesterol & 6.15 & 7.04 & 0.449 & 0.20 & 5.88 & 6.57 & 0.335 & 0.18 & 6.30 & 7.73 & 0.241 & $<0.01$ & 0.371 & 0.13 \\
\hline HDL & 5.38 & 6.22 & 0.370 & 0.15 & 5.33 & 6.02 & 0.196 & $<0.05$ & 5.36 & 6.25 & 0.110 & $<0.01$ & 0.279 & 0.83 \\
\hline LDL & 0.282 & 0.263 & 0.0442 & 0.76 & 0.249 & 0.231 & 0.0273 & 0.65 & 0.276 & 0.345 & 0.0284 & 0.13 & 0.0342 & 0.09 \\
\hline \multicolumn{15}{|c|}{ Fatty acid composition ( $\mathrm{g} / 100 \mathrm{~g}$ total fatty acids) } \\
\hline 14:0 & 0.61 & 1.19 & 0.029 & $<0.01$ & 1.43 & 1.31 & 0.074 & 0.28 & 1.35 & 1.19 & 0.080 & 0.18 & 0.077 & 0.46 \\
\hline 15:0 & 0.61 & 0.60 & 0.036 & 0.85 & 0.70 & 0.57 & 0.022 & $<0.01$ & 0.69 & 0.56 & 0.019 & $<0.01$ & 0.019 & 0.34 \\
\hline 16:0 & 8.62 & 9.09 & 0.152 & 0.06 & 10.09 & 9.29 & 0.158 & $<0.01$ & 9.80 & 8.72 & 0.201 & $<0.01$ & 0.170 & 0.10 \\
\hline $17: 0$ & 0.77 & $0.61^{\mathrm{a}}$ & 0.012 & $<0.01$ & 0.76 & $0.49^{\mathrm{b}}$ & 0.028 & $<0.01$ & 0.81 & $0.51^{\mathrm{b}}$ & 0.015 & $<0.01$ & 0.013 & $<0.01$ \\
\hline 18:0 & 13.36 & 14.08 & 0.185 & $<0.05$ & 13.00 & 13.67 & 0.35 & 0.21 & 13.65 & 14.14 & 0.243 & 0.19 & 0.203 & 0.24 \\
\hline 19:0 & 0.12 & 0.10 & 0.005 & $<0.05$ & 0.12 & 0.11 & 0.004 & 0.10 & 0.13 & 0.10 & 0.003 & $<0.01$ & 0.003 & 0.53 \\
\hline 20:0 & 0.07 & $0.06^{\mathrm{b}}$ & 0.005 & 0.61 & 0.08 & $0.07^{\mathrm{a}}$ & 0.006 & 0.20 & 0.09 & $0.06^{\mathrm{b}}$ & 0.004 & $<0.01$ & 0.002 & $<.01$ \\
\hline $14: 1 n-5$ & 0.01 & 0.07 & 0.002 & $<0.01$ & 0.08 & 0.07 & 0.005 & 0.43 & 0.07 & 0.07 & 0.004 & 0.39 & 0.004 & 0.58 \\
\hline $16: 1 \mathrm{n}-7$ & 0.58 & $0.68^{\mathrm{b}}$ & 0.031 & $<0.05$ & 0.73 & $0.82^{\mathrm{a}}$ & 0.036 & 0.10 & 0.68 & $0.71^{\mathrm{b}}$ & 0.045 & 0.70 & 0.033 & $<0.05$ \\
\hline $18: 1 n-9$ & 4.46 & $5.97^{\mathrm{b}}$ & 0.199 & $<0.01$ & 6.32 & $7.39^{\mathrm{a}}$ & 0.284 & $<0.05$ & 6.02 & $5.92^{\mathrm{b}}$ & 0.307 & 0.82 & 0.283 & $<0.01$ \\
\hline$\sum 18: 1 t 10 / 18 t 11$ & 0.79 & $1.24^{\mathrm{b}}$ & 0.048 & $<0.01$ & 1.21 & $1.91^{\mathrm{a}}$ & 0.053 & $<0.01$ & 1.16 & $1.36^{\mathrm{b}}$ & 0.052 & $<0.05$ & 0.063 & $<.01$ \\
\hline $20: 1 \mathrm{n}-11$ & 0.12 & $0.10^{\mathrm{b}}$ & 0.007 & $<0.05$ & 0.13 & $0.14^{\mathrm{a}}$ & 0.008 & 0.35 & 0.14 & $0.11^{\mathrm{b}}$ & 0.004 & $<0.01$ & 0.007 & $<0.01$ \\
\hline $18: 2 n-6$ & 42.16 & $42.38^{\mathrm{a}}$ & 1.486 & 0.92 & 37.10 & $33.40^{\mathrm{b}}$ & 1.437 & 0.11 & 36.43 & $39.79^{\mathrm{a}}$ & 1.40 & 0.13 & 1.088 & $<0.01$ \\
\hline $18: 3 n-6$ & 0.18 & 0.22 & 0.015 & 0.07 & 0.21 & 0.23 & 0.009 & 0.26 & 0.21 & 0.21 & 0.015 & 0.96 & 0.013 & 0.47 \\
\hline $20: 3 n-6$ & 1.75 & 1.51 & 0.153 & 0.29 & 1.59 & 1.20 & 0.128 & 0.07 & 1.58 & 1.30 & 0.037 & $<0.01$ & 0.093 & 0.11 \\
\hline $20: 4 n-6$ & 1.55 & 1.30 & 0.104 & 0.13 & 1.54 & 1.50 & 0.093 & 0.81 & 1.55 & 1.51 & 0.134 & 0.82 & 0.101 & 0.29 \\
\hline $18: 3 n-3$ & 12.46 & $9.25^{\mathrm{b}}$ & 1.222 & 0.10 & 12.59 & $14.30^{\mathrm{a}}$ & 1.059 & 0.29 & 13.45 & $11.79^{\mathrm{ab}}$ & 0.691 & 0.13 & 0.825 & $<0.01$ \\
\hline$\sum \mathrm{CLA}^{4}$ & 0.26 & $0.36^{\mathrm{c}}$ & 0.017 & $<0.01$ & 0.41 & $1.10^{\mathrm{a}}$ & 0.024 & $<0.01$ & 0.35 & $0.67^{\mathrm{b}}$ & 0.030 & $<0.01$ & 0.029 & $<0.01$ \\
\hline $18: 2 c 9 t 11$ & 0.13 & $0.27^{\mathrm{c}}$ & 0.012 & $<0.01$ & 0.28 & $0.61^{\mathrm{a}}$ & 0.020 & $<0.01$ & 0.23 & $0.43^{\mathrm{b}}$ & 0.019 & $<0.01$ & 0.020 & $<0.01$ \\
\hline $18: 2 t 10 c 12$ & 0.04 & $0.02^{\mathrm{C}}$ & 0.003 & $<0.01$ & 0.02 & $0.28^{\mathrm{a}}$ & 0.012 & $<0.01$ & 0.02 & $0.12^{\mathrm{b}}$ & 0.008 & $<0.01$ & 0.011 & $<0.01$ \\
\hline$\sum$ Saturated & 29.82 & 31.06 & 0.209 & $<0.01$ & 32.38 & 31.11 & 0.447 & 0.08 & 32.42 & 30.12 & 0.651 & $<0.05$ & 0.419 & 0.21 \\
\hline$\sum$ Unsaturated & 70.18 & 68.94 & 0.209 & $<0.01$ & 67.63 & 68.88 & 0.447 & 0.08 & 67.59 & 69.89 & 0.651 & $<0.05$ & 0.419 & 0.21 \\
\hline
\end{tabular}

concentrations of long chain fatty acids (LCFA; 18:0, 19:0, $20: 0)$. In the milk of $S$ cows the $14: 1 n-9$ concentration decreased $(p<0.01)$ whereas no changes $(p>0.05)$ were observed in the milk of the other treatments. The level of other MUFA (18:1n-9; 18:1t10/18:1t11; 20:1n-9) increased $(p<0.01$; except for 20:1n-9 in S) with all supplements from the AP to the EP. The increase $(p<0.01)$ of the $18: 2 n-6$ concentrations in the S and SC and the increase $(\mathrm{p}<0.05)$ of the CLA isomers concentrations in the $\mathrm{C}$ and SC treatments from AP to EP reflected the dietary intake of the respective fatty acids. Because supplement S contained no CLA, the observed increase in the concentration of the 18:2c9t11 isomer from the AP to the EP indicated that this increase is of endogenous origin. The $20: 3 n-6$ and the $20: 4 n-6$ concentrations remained unchanged $(p>0.05)$ over time in the $\mathrm{S}$ treatment whereas their concentrations decreased $(p<0.01)$ in treatment $C$ and SC. Compared to the AP, the concentration of $18: 3 n-3$ was unaffected $(p>0.05)$ in all treatments, that of $18: 3 n-6$ was decreased $(p<0.05)$ with $S$, and that of $20: 3 n-3$ was decreased $(p<0.05)$ with C and SC. All supplements increased $(p<0.01)$ the degree of desaturation of the milk fat.

In the EP, the concentration of SCFA, 12:0, and 14:0 were decreased $(p<0.01)$ to the same extent in the milk of cows fed the CLA supplemented diets (C and SC) compared to their concentrations in the milk fat of $S$ cows (Table 5). The only odd chain fatty acid that was affected by the treatments was $17: 0$, which was lower $(\mathrm{p}<0.01)$ in $\mathrm{S}$ than $\mathrm{C}$ and SC. Although the intake of 18:1n-9 was comparable for $\mathrm{C}$ and SC cows its concentration in the milk fat was higher $(\mathrm{p}<0.01)$ in SC cows. In accordance, the $23 \%$ increase (AP to EP) in the level of the elongation product $20: 1 n-9$ was similar to that observed for $18: 1 n-9(p<0.01)$. The higher the dietary CLA intake $(C>S C>S)$, the higher $(p<0.01)$ the $18: 1 t 10 / 18: 1 t 11$ and $18: 2 t 10 c 12$ concentrations in the milk fat. By contrast, the percentage of 18:2c9t11 and total CLA were similar in $\mathrm{C}$ and SC and lower in $\mathrm{S}(\mathrm{p}<0.01)$. Regardless of the amounts of sunflower seeds fed ( $S$ and 
Table 5. Fatty acid composition (g/100 g of total fatty acids) of the milk fat ${ }^{1}$

\begin{tabular}{|c|c|c|c|c|c|c|c|c|c|c|c|c|c|c|}
\hline \multirow{2}{*}{$\begin{array}{l}\text { Treatment } \\
\text { Period }^{3}\end{array}$} & \multicolumn{4}{|c|}{$S$} & \multicolumn{4}{|c|}{$\mathrm{C}$} & \multicolumn{4}{|c|}{ SC } & \multicolumn{2}{|c|}{ Treatment } \\
\hline & AP & EP & SEM & $\mathrm{p}$ value & $\mathrm{AP}$ & EP & SEM & $p$ value & $\mathrm{AP}$ & EP & SEM & $p$ value & SEM & $\mathrm{p}$ value \\
\hline 4:0 & 3.49 & $3.69^{\mathrm{a}}$ & 0.070 & 0.07 & 3.54 & $2.07^{\mathrm{b}}$ & 0.14 & $<0.01$ & 3.26 & $2.09^{b}$ & 0.173 & $<0.01$ & 0.142 & $<0.01$ \\
\hline $6: 0$ & 2.37 & $2.34^{\mathrm{a}}$ & 0.058 & 0.74 & 2.46 & $0.93^{\mathrm{b}}$ & 0.054 & $<0.01$ & 2.30 & $0.95^{\mathrm{b}}$ & 0.088 & $<0.01$ & 0.066 & $<0.01$ \\
\hline 8:0 & 1.42 & $1.33^{\mathrm{a}}$ & 0.058 & 0.28 & 1.55 & $0.47^{\mathrm{b}}$ & 0.045 & $<0.01$ & 1.43 & $0.49^{\mathrm{b}}$ & 0.046 & $<0.01$ & 0.038 & $<0.01$ \\
\hline 10:0 & 3.40 & $2.81^{\mathrm{a}}$ & 0.193 & 0.06 & 3.74 & $1.07^{\mathrm{b}}$ & 0.163 & $<0.01$ & 3.50 & $1.11^{\mathrm{b}}$ & 0.141 & $<0.01$ & 0.092 & $<0.01$ \\
\hline 12:0 & 4.06 & $3.07^{\mathrm{a}}$ & 0.233 & $<0.05$ & 4.40 & $1.70^{\mathrm{b}}$ & 0.163 & $<0.01$ & 4.22 & $1.73^{\mathrm{b}}$ & 0.181 & $<0.01$ & 0.103 & $<0.01$ \\
\hline 14:0 & 12.58 & $10.76^{\mathrm{a}}$ & 0.409 & $<0.05$ & 13.07 & $8.91^{\mathrm{b}}$ & 0.341 & $<0.01$ & 12.91 & $8.59^{\mathrm{b}}$ & 0.510 & $<0.01$ & 0.397 & $<0.01$ \\
\hline $15: 0$ & 1.17 & 0.91 & 0.064 & $<0.05$ & 1.20 & 0.91 & 0.069 & $<0.05$ & 1.18 & 0.95 & 0.024 & $<0.01$ & 0.031 & 0.59 \\
\hline $16: 0$ & 35.67 & 25.56 & 0.900 & $<0.01$ & 34.59 & 25.76 & 1.652 & $<0.01$ & 34.78 & 22.25 & 0.751 & $<0.01$ & 1.005 & 0.05 \\
\hline $17: 0$ & 0.51 & $0.45^{\mathrm{a}}$ & 0.015 & $<0.05$ & 0.52 & $0.54^{\mathrm{a}}$ & 0.015 & 0.33 & 0.51 & $0.57^{\mathrm{a}}$ & 0.017 & 0.06 & 0.016 & $<0.01$ \\
\hline 18:0 & 7.01 & 12.41 & 0.525 & $<0.01$ & 7.47 & 13.60 & 0.372 & $<0.01$ & 6.95 & 12.64 & 0.561 & $<0.01$ & 0.599 & 0.36 \\
\hline 19:0 & 0.07 & 0.12 & 0.004 & $<0.01$ & 0.08 & 0.12 & 0.006 & $<0.01$ & 0.08 & 0.11 & 0.005 & $<0.01$ & 0.007 & 0.39 \\
\hline 20:0 & 0.12 & 0.15 & 0.005 & $<0.01$ & 0.13 & 0.16 & 0.005 & $<0.01$ & 0.13 & 0.16 & 0.006 & $<0.01$ & 0.006 & 0.37 \\
\hline $14: 1 n-5$ & 1.25 & 0.94 & 0.043 & $<0.01$ & 1.12 & 0.92 & 0.113 & 0.24 & 1.22 & 1.09 & 0.104 & 0.43 & 0.085 & 0.31 \\
\hline $16: 1 n-7$ & 1.47 & 0.99 & 0.161 & 0.07 & 1.36 & 1.43 & 0.093 & 0.60 & 1.48 & 1.56 & 0.179 & 0.76 & 0.160 & 0.07 \\
\hline $18: 1 n-9$ & 13.75 & $18.99^{c}$ & 0.614 & $<0.01$ & 13.19 & $22.11^{\mathrm{b}}$ & 0.82 & $<0.01$ & 14.00 & $27.23^{\mathrm{a}}$ & 1.110 & $<0.01$ & 0.946 & $<0.01$ \\
\hline$\sum 18: 1 t 10 / 18 t 11$ & 1.64 & $2.84^{\mathrm{C}}$ & 0.103 & $<0.01$ & 1.69 & $5.31^{\mathrm{a}}$ & 0.189 & $<0.01$ & 1.66 & $3.80^{\mathrm{b}}$ & 0.158 & $<0.01$ & 0.210 & $<0.01$ \\
\hline $20: 1 n-9$ & 0.13 & $0.13^{\mathrm{b}}$ & 0.004 & 0.97 & 0.12 & $0.13^{\mathrm{b}}$ & 0.004 & $<0.05$ & 0.13 & $0.16^{\mathrm{a}}$ & 0.008 & $<0.05$ & 0.005 & $<0.01$ \\
\hline $18: 2 n-6$ & 1.86 & $2.56^{\mathrm{a}}$ & 0.103 & $<0.01$ & 1.74 & $1.94^{\mathrm{b}}$ & 0.128 & 0.30 & 1.78 & $2.84^{\mathrm{a}}$ & 0.171 & $<0.01$ & 0.126 & $<0.01$ \\
\hline $18: 3 n-6$ & 0.03 & $0.02^{\mathrm{b}}$ & 0.001 & $<0.05$ & 0.03 & $0.03^{\mathrm{a}}$ & 0.003 & 0.75 & 0.03 & $0.03^{\mathrm{a}}$ & 0.001 & 0.06 & 0.001 & $<0.01$ \\
\hline $20: 3 n-6$ & 0.07 & $0.07^{\mathrm{a}}$ & 0.009 & 0.79 & 0.07 & $0.04^{\mathrm{b}}$ & 0.005 & $<0.01$ & 0.07 & $0.05^{\mathrm{b}}$ & 0.005 & $<0.05$ & 0.005 & $<0.01$ \\
\hline $20: 4 n-6$ & 0.13 & $0.12^{\mathrm{a}}$ & 0.006 & 0.20 & 0.13 & $0.06^{\mathrm{c}}$ & 0.005 & $<0.01$ & 0.14 & $0.07^{\mathrm{b}}$ & 0.009 & $<0.01$ & 0.004 & $<0.01$ \\
\hline $18: 3 n-3$ & 1.04 & $0.95^{\mathrm{b}}$ & 0.063 & 0.34 & 1.12 & $1.06^{\mathrm{ab}}$ & 0.099 & 0.65 & 1.23 & $1.21^{\mathrm{a}}$ & 0.088 & 0.87 & 0.064 & $<0.05$ \\
\hline$\sum \mathrm{CLA}^{4}$ & 0.83 & $1.09^{\mathrm{b}}$ & 0.074 & $<0.05$ & 0.79 & $2.22^{\mathrm{a}}$ & 0.050 & $<0.01$ & 0.85 & $1.89^{\mathrm{a}}$ & 0.130 & $<0.01$ & 0.111 & $<0.01$ \\
\hline 18:2c9t11 & 0.77 & $1.01^{\mathrm{b}}$ & 0.071 & $<0.05$ & 0.74 & $1.74^{\mathrm{a}}$ & 0.054 & $<0.01$ & 0.79 & $1.60^{\mathrm{a}}$ & 0.126 & $<0.01$ & 0.110 & $<0.01$ \\
\hline $18: 2 t 10 c 12$ & $-{ }^{5}$ & $0.02^{\mathrm{c}}$ & 0.001 & $<0.01$ & - & $0.33^{\mathrm{a}}$ & 0.012 & $<0.01$ & - & $0.18^{\mathrm{b}}$ & 0.004 & $<0.01$ & 0.010 & $<0.01$ \\
\hline$\sum$ Saturated & 74.45 & $65.90^{\mathrm{a}}$ & 0.832 & $<0.01$ & 75.33 & $58.42^{\mathrm{b}}$ & 1.042 & $<0.01$ & 73.91 & $53.96^{c}$ & 1.763 & $<0.01$ & 1.363 & $<0.01$ \\
\hline$\sum$ Unsaturated & 25.37 & $33.98^{\mathrm{c}}$ & 0.841 & $<0.01$ & 24.47 & $41.52^{\mathrm{b}}$ & 1.047 & $<0.01$ & 25.89 & $45.98^{\mathrm{a}}$ & 1.763 & $<0.01$ & 1.363 & $<0.01$ \\
\hline \multicolumn{15}{|l|}{ Desaturase ratio $^{6}$} \\
\hline 14:1/14:0 & 0.10 & 0.09 & 0.005 & 0.09 & 0.09 & 0.10 & 0.011 & 0.32 & 0.10 & 0.13 & 0.017 & 0.16 & 0.014 & 0.11 \\
\hline $16: 1 / 16: 0$ & 0.04 & $0.04^{\mathrm{b}}$ & 0.004 & 0.69 & 0.04 & $0.06^{\mathrm{ab}}$ & 0.002 & $<0.01$ & 0.04 & $0.07^{\mathrm{a}}$ & 0.008 & $<0.05$ & 0.007 & $<0.05$ \\
\hline 18:1/18:0 & 1.98 & $1.55^{\mathrm{b}}$ & 0.122 & $<0.05$ & 1.77 & $1.62^{\mathrm{b}}$ & 0.051 & 0.09 & 2.06 & $2.20^{\mathrm{a}}$ & 0.222 & 0.65 & 0.139 & $<0.05$ \\
\hline
\end{tabular}

${ }^{1}$ Means within the same row with unequal superscripts are significantly different $(\mathrm{p}<0.05)$.

${ }^{2} \mathrm{~S}=$ Mixture of ground sunflower seeds, wheat middlings, molasses; C = Mixture of CLA-oil, wheat middlings, molasses; SC $=$ Mixture of ground sunflower seeds, CLA-oil, wheat middlings, molasses.

${ }^{3} \mathrm{AP}=$ Adjustment period; $\mathrm{EP}=$ Experimental period.

${ }^{4} \sum \mathrm{CLA}=\mathrm{C} 18: 2 \mathrm{c} 9 \mathrm{t} 11+\mathrm{C} 18: 2 \mathrm{c} 9 \mathrm{c} 11+\mathrm{C} 18: 2 \mathrm{t} 9 \mathrm{t} 11+\mathrm{C} 18: 2 \mathrm{t} 10 \mathrm{c} 12$.

${ }^{5}-<0.01$.

${ }^{6}$ Ratio for fatty acid pairs that represent product/substrate for $\Delta^{9}$-desaturase.

SC), the 18:2n-6 milk fat concentration was similar but was higher $(\mathrm{p}<0.01)$ than in treatment $\mathrm{C}$. When sunflower seeds were the sole source of dietary fat, the 18:3n-6 concentration was lowest whereas the 20:3n- 6 and 20:4n-6 concentrations were highest $(\mathrm{p}<0.01)$. With a similar $18: 3 n-3$ intake the concentration of $18: 3 n-3$ in the milk fat was lower in S compared to SC $(\mathrm{p}<0.05)$ but did not differ from $C$. The degree of unsaturation of the milk fat was lowest in the S, highest in the SC and intermediate in the $\mathrm{C}$ group $(\mathrm{p}<0.01)$.

In all treatments the amount of secreted SCFA, MCFA, $14: 1 n-5,16: 1 n-7,18: 3 n-6,20: 3 n-6,20: 4 n-6$, and 18:3n-3 decreased $(\mathrm{p}<0.05)$ and reflected the decreased milk fat yield from AP to EP (Table 6). Regarding the odd chain fatty acids, the total amount of 15:0 and 17:0 was lower $(\mathrm{p}<0.01)$ in all treatments, whereas the amount of 19:0 decreased $(\mathrm{p}<0.05)$ in $\mathrm{C}$ and SC but increased $(\mathrm{p}<0.01)$ in $\mathrm{S}$. The daily amount of secreted 18:0 increased $(p<0.01)$ in $S$, decreased $(\mathrm{p}<0.05)$ in $\mathrm{C}$ and remained unchanged in SC, whereas the amount of $18: 1 n-9$ was lowered $(\mathrm{p}<0.01)$ only in C. When CLA was fed lower $(p<0.01)$ amount of 20:0 was found in treatment $C$ and SC whereas for 20:1n-9 lower $(p<0.05)$ secretion was observed in all treatments from AP to EP. The amount of $18: 1 t 10 / 18: 1 t 11$ only increased $(\mathrm{p}<0.01)$ in the $\mathrm{S}$ group. In all treatments, no $(\mathrm{p}>0.05)$ differences in the total amounts of secreted CLA and $18: 2 c 9 t 11$ isomer were observed whereas the amount of the $18: 2 t 10 c 12$ isomer markedly increased $(\mathrm{p}<0.01)$ from AP to EP. The total amount of secreted 18:2n-6 decreased $(p<0.01)$ in treatment $C$ but not $(p=0.27)$ in treatment $S$ and SC. From AP to EP the amount of saturated milk fat decreased in all treatments but only in treatment $C$ the 
Table 6. Daily secretion of fatty acids (g/d) in the milk fat ${ }^{1}$

\begin{tabular}{|c|c|c|c|c|c|c|c|c|c|c|c|c|c|c|}
\hline \multirow{2}{*}{$\begin{array}{l}\text { Treatment }{ }^{2} \\
\text { Period }^{3}\end{array}$} & \multicolumn{4}{|c|}{$\mathrm{S}$} & \multicolumn{4}{|c|}{ C } & \multicolumn{4}{|c|}{ SC } & \multicolumn{2}{|c|}{ Treatment } \\
\hline & $\mathrm{AP}$ & EP & SEM & $\overline{p \text { value }}$ & AP & EP & SEM & p value & AP & EP & SEM & $\overline{p \text { value }}$ & SEM & $\mathrm{p}$ value \\
\hline 4:0 & 43.96 & $37.83^{\mathrm{a}}$ & 1.777 & $<0.05$ & 42.20 & $10.17^{\mathrm{b}}$ & 2.343 & $<0.01$ & 34.32 & $11.76^{\mathrm{b}}$ & 3.110 & $<0.01$ & 1.872 & $<0.01$ \\
\hline $6: 0$ & 29.75 & $23.96^{\mathrm{a}}$ & 1.069 & $<0.01$ & 29.25 & $4.60^{\mathrm{b}}$ & 1.079 & $<0.01$ & 24.17 & $5.37^{\mathrm{b}}$ & 1.962 & $<0.01$ & 1.020 & $<0.01$ \\
\hline 8:0 & 17.84 & $13.61^{\mathrm{a}}$ & 0.671 & $<0.01$ & 18.35 & $2.32^{\mathrm{b}}$ & 0.623 & $<0.01$ & 14.98 & $2.78^{\mathrm{b}}$ & 1.127 & $<0.01$ & 0.574 & $<0.01$ \\
\hline 10:0 & 42.54 & $28.80^{\mathrm{a}}$ & 1.978 & $<0.01$ & 44.13 & $5.30^{\mathrm{b}}$ & 1.528 & $<0.01$ & 36.87 & $6.29^{\mathrm{b}}$ & 2.896 & $<0.01$ & 1.385 & $<0.01$ \\
\hline 12:0 & 50.72 & $31.45^{\mathrm{a}}$ & 2.334 & $<0.01$ & 51.91 & $8.42^{\mathrm{b}}$ & 1.324 & $<0.01$ & 44.34 & $9.63^{b}$ & 3.478 & $<0.01$ & 1.562 & $<0.01$ \\
\hline $14: 0$ & 157.91 & $110.23^{\mathrm{a}}$ & 5.587 & $<0.01$ & 154.61 & $44.37^{\mathrm{b}}$ & 3.929 & $<0.01$ & 134.87 & $47.77^{\mathrm{b}}$ & 9.657 & $<0.01$ & 6.247 & $<0.01$ \\
\hline 15:0 & 14.87 & $9.30^{\mathrm{a}}$ & 1.162 & $<0.01$ & 14.29 & $4.49^{\mathrm{b}}$ & 0.863 & $<0.01$ & 12.21 & $5.14^{\mathrm{b}}$ & 0.641 & $<0.01$ & 0.509 & $<0.01$ \\
\hline 16:0 & 452.45 & $261.45^{\mathrm{a}}$ & 24.722 & $<0.01$ & 411.31 & $129.56^{\mathrm{b}}$ & 22.100 & $<0.01$ & 365.43 & $121.40^{\mathrm{b}}$ & 28.568 & $<0.01$ & 15.246 & $<0.01$ \\
\hline $17: 0$ & 6.51 & $4.63^{\mathrm{a}}$ & 0.396 & $<0.01$ & 6.14 & $2.63^{\mathrm{b}}$ & 0.288 & $<0.01$ & 5.32 & $3.10^{\mathrm{b}}$ & 0.417 & $<0.01$ & 0.332 & $<0.01$ \\
\hline 18:0 & 87.77 & $127.87^{\mathrm{a}}$ & 8.201 & $<0.01$ & 88.93 & $66.49^{\mathrm{b}}$ & 5.534 & $<0.05$ & 73.21 & $69.96^{\mathrm{b}}$ & 10.390 & 0.83 & 9.888 & $<0.01$ \\
\hline 19:0 & 0.94 & $1.21^{\mathrm{a}}$ & 0.040 & $<0.01$ & 0.90 & $0.62^{\mathrm{b}}$ & 0.070 & $<0.05$ & 0.84 & $0.59^{\mathrm{b}}$ & 0.078 & $<0.05$ & 0.069 & $<0.01$ \\
\hline 20:0 & 1.56 & $1.56^{\mathrm{a}}$ & 0.100 & 0.98 & 1.49 & $0.81^{\mathrm{b}}$ & 0.093 & $<0.01$ & 1.32 & $0.87^{\mathrm{b}}$ & 0.143 & 0.06 & 0.123 & $<0.01$ \\
\hline $14: 1 n-5$ & 15.87 & $9.56^{\mathrm{a}}$ & 0.813 & $<0.01$ & 13.34 & $4.61^{\mathrm{b}}$ & 1.188 & $<.01$ & 12.43 & $5.76^{\mathrm{b}}$ & 0.581 & $<0.01$ & 0.523 & $<0.01$ \\
\hline $16: 1 n-7$ & 18.83 & 10.17 & 2.254 & $<0.05$ & 16.25 & 7.16 & 1.268 & $<0.01$ & 15.08 & 7.91 & 0.431 & $<.01$ & 1.070 & 0.16 \\
\hline $18: 1 n-9$ & 173.62 & $194.39^{\mathrm{a}}$ & 11.662 & 0.24 & 157.25 & $107.35^{c}$ & 10.153 & $<0.01$ & 143.93 & $144.29^{b}$ & 9.538 & 0.98 & 9.871 & $<0.01$ \\
\hline $\begin{array}{r}\Sigma 18: 1 \mathrm{t} 10 \\
/ 18: 1 \mathrm{t} 11\end{array}$ & 20.71 & $28.80^{\mathrm{a}}$ & 0.638 & $<0.01$ & 20.00 & $25.81^{\mathrm{ab}}$ & 1.835 & 0.06 & 17.24 & $20.53^{\mathrm{b}}$ & 2.014 & 0.28 & 2.026 & $<0.05$ \\
\hline 20:1n-9 & 1.61 & $1.31^{\mathrm{a}}$ & 0.081 & $<0.05$ & 1.38 & $0.65^{\mathrm{b}}$ & 0.075 & $<0.01$ & 1.34 & $0.87^{\mathrm{b}}$ & 0.071 & $<0.01$ & 0.077 & $<0.01$ \\
\hline $18: 2 n-6$ & 23.40 & $26.30^{\mathrm{a}}$ & 1.745 & 0.27 & 20.87 & $9.58^{c}$ & 1.100 & $<0.01$ & 18.56 & $15.28^{\mathrm{b}}$ & 1.969 & 0.27 & 1.579 & $<0.01$ \\
\hline $18: 3 n-6$ & 0.33 & $0.23^{\mathrm{a}}$ & 0.019 & $<0.01$ & 0.34 & $0.15^{\mathrm{b}}$ & 0.028 & $<0.01$ & 0.26 & $0.16^{\mathrm{b}}$ & 0.017 & $<0.01$ & 0.019 & $<0.05$ \\
\hline $20: 3 n-6$ & 0.88 & $0.76^{\mathrm{a}}$ & 0.105 & 0.41 & 0.87 & $0.22^{\mathrm{b}}$ & 0.042 & $<0.01$ & 0.78 & $0.30^{\mathrm{b}}$ & 0.079 & $<0.01$ & 0.062 & $<0.01$ \\
\hline $20: 4 n-6$ & 1.67 & $1.24^{\mathrm{a}}$ & 0.092 & $<0.05$ & 1.54 & $0.29^{\mathrm{b}}$ & 0.073 & $<0.01$ & 1.45 & $0.39^{\mathrm{b}}$ & 0.072 & $<0.01$ & 0.059 & $<0.01$ \\
\hline $18: 3 n-3$ & 13.31 & $9.76^{\mathrm{a}}$ & 1.087 & $<0.05$ & 13.55 & $5.28^{\mathrm{b}}$ & 1.357 & $<.01$ & 12.63 & $6.58^{\mathrm{b}}$ & 0.881 & $<0.01$ & 0.761 & $<0.01$ \\
\hline$\Sigma \mathrm{CLA}^{4}$ & 10.48 & 10.97 & 0.709 & 0.64 & 9.39 & 10.84 & 0.755 & 0.21 & 8.62 & 9.96 & 0.671 & 0.20 & 0.705 & 0.56 \\
\hline 18:2c9t11 & 9.78 & 10.16 & 0.674 & 0.70 & 8.70 & 8.47 & 0.658 & 0.81 & 8.05 & 8.38 & 0.558 & 0.69 & 0.579 & 0.09 \\
\hline 18:2t10c12 & $-{ }^{5}$ & $0.17^{\mathrm{c}}$ & 0.005 & $<0.01$ & - & $1.63^{\mathrm{a}}$ & 0.104 & $<0.01$ & - & $0.99^{\mathrm{b}}$ & 0.097 & $<0.01$ & 0.114 & $<0.01$ \\
\hline$\Sigma$ saturated & 939.27 & $675.42^{\mathrm{a}}$ & 37.790 & $<0.01$ & 894.27 & $290.48^{\mathrm{b}}$ & 31.063 & $<0.01$ & 775.50 & $297.42^{\mathrm{b}}$ & 60.901 & $<0.01$ & 37.198 & $<0.01$ \\
\hline$\Sigma$ unsaturated & 320.64 & $347.05^{\mathrm{a}}$ & 17.615 & 0.32 & 291.91 & $202.31^{\mathrm{b}}$ & 18.149 & $<0.01$ & 266.62 & $244.50^{\mathrm{b}}$ & 17.956 & 0.41 & 17.062 & $<0.01$ \\
\hline
\end{tabular}

amount of unsaturated milk fat was lowered $(\mathrm{p}<0.01)$.

The majority of the observed treatment differences in the amount of the milk fatty acids are the result of the markedly higher milk fat yield in S compared to the other treatments in the EP (Table 6). Despite the higher milk fat yield in treatment $\mathrm{S}$, the amount of secreted 18:2c9t11 and total CLA were similar ( $p>0.05)$ in all treatments because of their higher concentrations in the milk fat of cows fed $\mathrm{C}$ or SC. As expected the amount of secreted 18:2t10c12 isomer was highest in C cows followed by the SC cows and very low amounts in $\mathrm{S}$ cows.

\section{DISCUSSION}

Inclusion of plant lipids rich in PUFA in the diets can depress the forage intake of dairy cows (Shingfield et al., 2008). The main reasons are PUFA induced negative effects on ruminal fermentation and a shift of fiber digestibility to the hindgut, which is less efficient (Jenkins, 1993).
However, in the present study increased 18:2n-6 intake from about $100 \mathrm{~g} / \mathrm{d}$ in the AP to $400 \mathrm{~g} / \mathrm{d}$ in the EP in treatment $\mathrm{S}$ had no effect on intake. By contrast, in treatment C and SC CLA inclusion to the basal diet resulted in a significant forage intake depression suggesting that the composition rather than the amount of ingested PUFA was determinant for the observed effect. Galbraith et al. (1971) reported that numbers of double bounds and isomerism of long chain dietary fatty acids are factors inhibiting grampositive bacteria. Another explanation for the different effect of 18:2n-6 and CLA on hay intake might be the extent to which the fatty acid source is available in the rumen. Fatty acids from oilseeds may be rumen-protected because of the hulls. However, this explanation is not valid in the present case because the sunflower seeds used were ground and the integrity of the hulls was compromised. In accordance, Duckett et al. (2002) did not find an effect on DMI of beef steers when rolled high oil corn was fed compared to rolled typical corn supplemented with corn oil. 
In general, supplementing diets of dairy cows with dietary fat increases plasma concentrations of triglyceride (Palmquist and Conrad, 1978; Lough et al., 1988) and NEFA (Grummer and Carroll, 1991; Gonthier et al., 2005). However, NEFA levels remained unchanged when untreated whole sunflower seeds were offered to dairy cows compared to an unsupplemented control (Petit et al., 2004). The latter concurs with what one could observe in treatment $\mathrm{S}$ when cows were switched from an unsupplemented to a sunflower seed fortified diet. By contrast, when CLA was added to the diet ( $\mathrm{C}$ and SC) NEFA level increased, which is in contrast to findings of other studies (Baumgard et al., 2002a; Perfield et al., 2002). Reasons for the difference in response of CLA and sunflower seed to NEFA concentrations are unclear. However, cows in all 3 treatment-groups were in mid lactation and therefore mobilization of fatty acids from the adipose tissue is unlikely to occur. Grummer and Carroll (1991) supposed that an increase in NEFA during lipid supplementation might result from incomplete tissue uptake of fatty acids after lipoprotein lipase hydrolysis of VLDL. Furthermore, higher NEFA levels might result from net adipose tissue triglyceride hydrolysis during lipid supplementation (Palmquist and Conrad, 1978; Grummer and Carroll, 1991). However, in the present study dietary lipid level but not the lipid source increased plasma triglyceride levels. The impact of dietary lipid content and fatty acid composition on plasma cholesterol concentrations and the associated LDL and HDL levels are inconsistent. In a review paper Grummer and Carroll (1991) concluded that feeding fat to dairy cows almost always increases plasma cholesterol levels whereas the degree of fatty acid saturation had no effect. Contrarily, Petit (2002) reported higher cholesterol and HDL plasma concentrations when dairy cows received plant lipids either rich in 16:0 or 18:2n-6 compared to plant lipids rich in 18:3n-3 The latter partly concurs with our findings because when CLA alone or combined with sunflower seeds (C and SC) were offered plasma cholesterol and HDL levels increased, respectively. Data about the effect of CLA feeding on plasma LDL and HDL concentrations in dairy cows are rare. Compared to a nonenriched control diet, feeding 18:2c9t11 and 18:1t11 enriched butter to hamsters decreased LDL concentration but had no effect on HDL concentration (Lock et al., 2005). In a study where men consumed either 18:2c9t11 or 18:2t10c12 at 3 doses, plasma cholesterol and LDL concentrations were influenced both by isomer and dose whereas HDL concentration remained unaffected (Tricon et al., 2004).

It is well established that unsaturated fatty acids such as 18:2n-6 undergo extensive $\mathrm{BH}$ in the rumen and involves the formation of $18: 2 \mathrm{c} 9 \mathrm{t} 11$ and $18: 1 \mathrm{t} 11$ as major intermediates with 18:0 being the final product. Recently,
Shingfield et al. (2005) reported that increasing ruminal outflow of 18:1t11 from sunflower seed oil was 10-times higher compared with 18:2c9t11, which suggests that, the metabolism of $18: 2 \mathrm{c} 9 \mathrm{t} 11$ to $18: 1 \mathrm{t} 11$ occurs at a faster rate than the conversion of 18:1t11 to 18:0. In accordance, in the present study the concentration in the plasma and the milk yield of trans-monoenic acid (sum of 18:1t10 and 18:1t11) increased markedly after cows were offered sunflower seed. By contrast, the 18:2n-6 plasma concentration and the $18: 2 n-6$ yield in the milk of $S$ cows did not differ from AP to EP. The lack of change in concentration observed in this study concurs with results reported by Shingfield et al. (2005) who determined that $97.6 \%$ of $18: 2 n-6$ originating from sunflower seed oil was biohydrogenated. Furthermore, milk of $\mathrm{S}$ cows contained also a small amount of the $18: 2 \mathrm{t} 10 \mathrm{c} 12$ isomer, confirming previous findings that $18: 2 \mathrm{t} 10 \mathrm{c} 12$ was as well a minor ruminal biohydrogenation product of 18:2n-6 (Duckett et al., 2002; Shingfield et al., 2005). The 18:2t10c12 is a known inhibitor of milk fat lipogenesis in lactating cows (Baumgard et al., 2000; Baumgard et al., 2002b) and although its increase (from not detectable to $0.07 \mathrm{~g} / 100 \mathrm{~g}$ total fatty acids) was marginal, milk fat synthesis was significantly reduced by $20 \%$ in S cows. However, when cows were offered the same amount of 18:2 as 18:2c9t11/t10c12 milk fat yield dropped by $60 \%$ with no effect on milk yield. To our knowledge there is just one other experiment described in a meeting abstract which investigated the impact of unprotected CLA on milk fat and the concentration of its isomer (Hawley et al., 2001). In that study, the daily amount of CLA offered was $100 \mathrm{~g}$ compared to $400 \mathrm{~g}$ in the present study. The increase in 18:2c9t11 in the milk fat was similar to that observed when safflower oil and Ca salts of CLA was fed. Milk fat depression occurred with unprotected CLA but was less then when $\mathrm{Ca}$ salts were utilized. Combining data of 7 studies in which lactating dairy cows were abomasally infused with 18:2t10c12 de Veth et al. (2004) found a strong relationship between the abomasal infusion doses of $18: 2 t 10 c 12$ and its secretion in the milk. Based on this equation, we estimated that of the $144 \mathrm{~g} / \mathrm{d}$ only $0.37 \mathrm{~g} / \mathrm{d}$ of $18: 2 \mathrm{t} 10 \mathrm{c} 12$ reached the abomasum; thus, $99.83 \%$ of the daily intake of this fatty acid was biohydrogenated. Apparently, the $\mathrm{BH}$ rate does not differ depending on the amount of 18:2t10c12 supplied because the estimated $\mathrm{BH}$ rate in treatment SC was $99.81 \%$. This estimation was confirmed by the concentrations found in the plasma and milk which were in treatment SC about half of those found in treatment $\mathrm{C}$. Thus, compared to $\mathrm{Ca}$ salt of CLA (Castaneda-Gutierrez et al., 2005; Perfield et al., 2002) transfer efficiency was with 0.77 and $0.84 \%$ in treatment C and SC, respectively, markedly lower. When the amount of $18: 2 \mathrm{t} 10 \mathrm{c} 12$, which is not metabolized in the rumen, is taken into account, the transfer rate amounted to $23 \%$. The latter 
is comparable to values obtained in studies utilizing abomasal infusion of 18:2t10c12 (Baumgard et al., 2001). The effect of 18:2t10c12 on MFD was similar in treatment $\mathrm{C}$ and SC as milk fat yield did not differ between treatments. Using the exponential decay equation proposed by De Veth et al. (2004) fitting the relationship between the change in milk fat yield and milk fat content of 18:2t10c12, the decrease in the milk fat yield amounted to $-45 \%$ in the current experiment. As observed by others using rumenprotected CLA (Perfield et al., 2002) the magnitude of reduction in milk fat is, especially for treatment $\mathrm{C}(-60 \%)$, much greater than predicted by the aforementioned equation. The supply of unprotected 18:2c9t11 resulted in a marked increase of this isomer in the plasma but not in the milk. However, the differences between $\mathrm{C}$ and SC treatments did not reflect the dietary supply, being higher in SC as expected. Because a large amount of this isomer in the milk fat is synthesized from $18: 1 \mathrm{t} 11$ by $\Delta 9$-desaturase in the mammary gland it is difficult to estimate the $\mathrm{BH}$ rate of this isomer. Nevertheless, the significantly higher plasma concentrations of this isomer in C and SC cows suggest that a certain amount also escaped the rumen.

\section{CONCLUSIONS}

Although unprotected dietary CLA underwent intensive $\mathrm{BH}$ the milk fat reduction was tremendous. This finding confirms that accumulation of CLA in the rumen is sufficient to enrich CLA in the milk and enforce known effects of CLA on milk fat synthesis. Avoiding the costs of producing a rumen-stable CLA source, unprotected CLA could be included in dairy cow diets during nutritional and environmental challenges with the goal to reduce the proportion of nutrient supply required for milk fat synthesis. This might improve cows' well being and allow them to cope with such challenges in an effective manner.

\section{ACKNOWLEDGEMENTS}

The authors thank J. Sturny (ALP) for his invaluable technical assistance in conducting the experiment, $M$. Collomb (ALP) for the fatty acids analysis and the BASFAG, Offenbach, Germany, for providing the CLA-oil.

\section{REFERENCES}

ALP (Agroscope Liebefeld-Posieux). 2010. Fütterungsempfehlungen und Nährwerttabellen für Wiederkäuer. Online-edition. Ed.: Forschungsanstalt Agroscope Liebefeld-Posieux ALP, Posieux, Switzerland.

AOAC. 1990. Official methods of analysis. Association of Official Analytical Chemists, Arlington, VA.

Baumgard, L. H., B. A. Corl, D. A. Dwyer, A. Saebo and D. E. Bauman. 2000. Identification of the conjugated linoleic acid isomer that inhibits milk fat synthesis. Am. J. Physiol. Regul. Integr. Comp. Physiol. 278:R179-R184.

Baumgard, L. H., J. K. Sangster and D. E. Bauman. 2001. Milk fat synthesis in dairy cows is progressively reduced by increasing supplemental amounts of trans-10, cis-12 conjugated Linoleic acid (CLA). J. Nutr. 131:1764-1769.

Baumgard, L. H., B. A. Corl, D. A. Dwyer and D. E. Bauman. 2002a. Effects of conjugated linoleic acids (CLA) on tissue response to homeostatic signals and plasma variables associated with lipid metabolism in lactating dairy cows. J. Anim. Sci. 80:1285-1293.

Baumgard, L. H., E. Matitashvili, B. A. Corl, D. A. Dwyer and D. E. Bauman. 2002b. Trans-10, cis-12 conjugated linoleic acid decreases lipogenic rates and expression of genes involved in milk lipid synthesis in dairy cows. J. Dairy Sci. 85:2155-2163.

Beam, T. M., T. C. Jenkins, P. J. Moate, R. A. Kohn and D. L. Palmquist. 2000. Effects of amount and source of fat on the rates of lipolysis and biohydrogenation of fatty acids in ruminal contents. J. Dairy Sci. 83:2564-2573.

Castaneda-Gutierrez, E., T. R. Overton, W. R. Butler and D. E. Bauman. 2005. Dietary supplements of two doses of calcium salts of conjugated linoleic acid during the transition period and early lactation. J. Dairy Sci. 88:1078-1089.

Collomb, M. and T. Bühler. 2000. Analysis of the fatty acid composition of the milk fat. I. Optimisation and validation of a general method adapted to the research. Mitt. Lebensm. Hyg. 91:306-332.

Collomb, M., H. Sollberger, U. Butikofer, R. Sieber, W. Stoll and W. Schaeren. 2004. Impact of a basal diet of hay and fodder beet supplemented with rapeseed, linseed and sunflowerseed on the fatty acid composition of milk fat. Int. Dairy J. 14:549559.

De Veth, M. J., J. M. Griinari, A. M. Pfeiffer and D. E. Bauman. 2004. Effect of CLA on milk fat synthesis in dairy cows: comparison of inhibition by methyl esters and free fatty acids, and relationships among studies. Lipids 39:365-372.

Duckett, S. K., J. G. Andrae and F. N. Owens. 2002. Effect of high-oil corn or added corn oil on ruminal biohydrogenation of fatty acids and conjugated linoleic acid formation in beef steers fed finishing diets. J. Anim. Sci. 80:3353-3360.

Galbraith, H., T. B. Miller, A. M. Paton and J. K. Thompson. 1971. Antibacterial activity of long chain fatty acids and the reversal with calcium, magnesium, ergocalciferol and cholesterol. J. Appl. Microbiol. 34:803-813.

Gonthier, C., A. F. Mustafa, D. R. Ouellet, P. Y. Chouinard, R. Berthiaume and H. V. Petit. 2005. Feeding micronized and extruded flaxseed to dairy cows: Effects on blood parameters and milk fatty acid composition. J. Dairy Sci. 88:748-756.

Griinari, J. M., B. A. Corl, S. H. Lacy, P. Y. Chouinard, K. V. V. Nurmela and D. E. Bauman. 2000. Conjugated linoleic acid is synthesized endogenously in lactating dairy cows by Delta9desaturase. J. Nutr. 130:2285-2291.

Grummer, R. R. and D. J. Carroll. 1991. Effects of dietary fat on metabolic disorders and reproductive performance of dairy cattle. J. Anim. Sci. 69:3838-3852.

Gulati, S. K., J. R. Ashes and T. W. Scott. 1999. Hydrogenation of eicosapentaenoic and docosahexaenoic acids and their incorporation into milk fat. Anim. Feed Sci. Technol. 79:57-64. Gulati, S. K., S. M. Kitessa, J. R. Ashes, E. Fleck, E. B. Byers, Y. 
G. Byers and T. W. Scott. 2000. Protection of conjugated linoleic acids from ruminal hydrogenation and their incorporation into milk fat. Anim. Feed Sci. Technol. 86:139148.

Hawley, M., M. McGuire, T. Hanson and A. Kertz. 2001. Conjugated linoleic acid (CLA) must be protected from rumen hydrogenation for greatest impact on milk composition. J. Anim. Sci. 79(Suppl. 1):355.

FIL-IDF (International Dairy Federation). 2000. Determination of milk fat, protein and lactose content. Guidance on the operation of mid-infrared instruments. Joint IDF/ISO/AOAC International Standard. Description/principle: IR spectrometric. Brussels, Belgium.

IUPAC (International Union of Pure and Applied Chemistry). 1987. Standard methods for the analysis of oils, fats and derivates. Blackwell Scientific Publications, Oxford (UK).

Jenkins, T. C. 1993. Lipid metabolism in the rumen. J. Dairy Sci. 76:3851-3863.

Lock, A. L., C. A. M. Horne, D. E. Bauman and A. M. Salter. 2005. Butter naturally enriched in conjugated linoleic acid and vaccenic acid alters tissue fatty acids and improves the plasma lipoprotein profile in cholesterol-fed hamsters. J. Nutr. 135:1934-1939.

Lough, D. S., L. D. Muller, R. S. Kensinger, T. F. Sweeney and L. C. Griel, Jr. 1988. Effect of added dietary fat and bovine somatotropin on the performance and metabolism of lactating dairy cows. J. Dairy Sci. 71:1161-1169.

Mertens, D. R. 2002. Gravimetric determination of amylasetreated neutral detergent fiber in feeds with refluxing in beakers or crucibles: Collaborative study. J. AOAC Int. 85:1217-1240.

Mosley, E. E., B. Shafii, P. J. Moate and M. A. McGuire. 2006. cis-9, trans-11 conjugated linoleic acid is synthesized directly from vaccenic acid in lactating dairy cattle. J. Nutr. 136:570575.

Palmquist, D. L. and H. R. Conrad. 1978. High fat rations for dairy cows. Effects on feed intake, milk and fat production, and plasma metabolites. J. Dairy Sci. 61:890-901.
Perfield, J. W., G. Bernal-Santos, T. R. Overton and D. E. Bauman. 2002. Effects of dietary supplementation of rumen-protected conjugated linoleic acid in dairy cows during established lactation. J. Dairy Sci. 85:2609-2617.

Petit, H. V. 2002. Digestion, milk production, milk composition, and blood composition of dairy cows fed whole flaxseed. J. Dairy Sci. 85:1482-1490.

Petit, H. V., C. Germiquet and D. Lebel. 2004. Effect of feeding whole, unprocessed sunflower seeds and flaxseed on milk production, milk composition, and prostaglandin secretion in dairy cows. J. Dairy Sci. 87:3889-3898.

Sackmann, J. R., S. K. Duckett, M. H. Gillis, C. E. Realini, A. H. Parks and R. B. Eggelston. 2003. Effects of forage and sunflower oil levels on ruminal biohydrogenation of fatty acids and conjugated linoleic acid formation in beef steers fed finishing diets. J. Anim. Sci. 81:3174-3181.

SAS Institute. 2004. SAS/STAT 9.1 user's guide. SAS Institute, Inc, Cary, NC, USA.

Shingfield, K. J., C. K. Reynolds, B. Lupoli, V. Toivonen, M. P. Yurawecz, P. Delmonte, J. M. Griinari, A. S. Grandison and D. E. Beever. 2005. Effect of forage type and proportion of concentrate in the diet on milk fatty acid composition in cows given sunflower oil and fish oil. Anim. Sci. 80:225-238.

Shingfield, K. J., S. Ahvenjarvi, V. Toivonen, A. Vanhatalo and P. Huhtanen. 2007. Transfer of absorbed cis-9, trans-11 conjugated linoleic acid into milk is biologically more efficient than endogenous synthesis from absorbed vaccenic acid in lactating cows. J. Nutr. 137:1154-1160.

Shingfield, K. J., S. Ahvenjarvi, V. Toivonen, A. Vanhatalo, P. Huhtanen and J. M. Griinari. 2008. Effect of incremental levels of sunflower-seed oil in the diet on ruminal lipid metabolism in lactating cows. Br. J. Nutr. 99:971-983.

Tricon, S., G. C. Burdge, S. Kew, T. Banerjee, J. J. Russell, E. L. Jones, R. F. Grimble, C. M. Williams, P. Yaqoob and P. C. Calder. 2004. Opposing effects of cis-9,trans-11 and trans10 ,cis-12 conjugated linoleic acid on blood lipids in healthy humans. Am. J. Clin. Nutr. 80:614-620. 